\title{
Thinking through Queer Theory
}

\author{
Eve Kosofsky Sedgwick
}

\begin{abstract}
イヴ・コゾフスキィ・セジウィック教授は、現在ニューヨーク市立大学の教授 であり、クイア理論およびセクシュアリティの研究の世界的な第一人者である。 またセクシュアリティのみならず、大きくフェミニズムの領域においても、学問 研究に留まらず、運動の面でも大きな影響を与えている。著書は多数あるが、 Between Men (1985)では「ホモソーシャルな欲望」という概念を提示し、Epistemology of the Closet (1990) [外岡尚美訳『クローゼットの認識論』青土社、1999］では、 クローゼットの可視性／不可視性のパラドックスを鋭く突いた。彼女の独創性 のひとつは、女や非＝異性愛の位置ではなく、異性愛の男の位置を分析するこ とによって、性の言説に切り込んだことである。著書は他にTendencies (1993)、 Fat Art, Thin Art (1994)などがある。

本講演は 2000 年10月 7 日に本学の言語文化学科英語圈コースと共催して、セジ ウィック教授を招聘した折の公開講演会のものである。講演会では最新作 A Dialogue on Love (1999)の朗読も行われた。

なお、本稿は竹村和子 (本学助教授)、大橋洋一（東京大学教授）により翻訳 されて『現代思想』2000年12月号（青土社）に掲載されている。
\end{abstract}

To begin with, I would like to thank all my hosts at Ochanomizu University for their very kind invitation to speak to you today. I am most grateful for the opportunity to do so, as well as for all the generous hospitality I have encountered here.

But besides being exciting, it is also sobering to speak about important cultural issues while visiting a country with whose history and institutions I am so sadly unfamiliar. Please believe that the insistently American emphasis of these comments does not represent any lack of interest in the very different Japanese experience. Instead, I hope you will hear my lecture as a very heartfelt invitation to join in a comparative conversation that will enable us to share more fully.

It seems like a great privilege now to be able to look back at twenty years of close involvement with feminist and queer thought, writing, teaching, and activism in the US. In retrospect, I can see that there are two basic principles that have animated all my work in these areas. These are not so much ethical principles as, I suppose, something like character traits, a mental idiom, or a consistent intellectual aesthetic.

The first of these is a very thoroughgoing conceptual habit of nondualism. As soon as anybody posits "concept $\mathrm{X}$ as opposed to concept $\mathrm{Y}$," I'm always the person who reflexively responds, "But maybe X and $\mathrm{Y}$ aren't so distinct from each other after all." Because of this nondualism, the methodological tools of 
deconstruction have always been congenial to me. I'm also extremely interested in Buddhist thought for the same reason.

The second mental habit is closely related to nondualism, but transferred into a more political sphere: that is, I have very little patience with separatism of any kind. This is true both for groups within which I could be included, such as separatist feminism or Jewish nationalism, and also those from which I would be excluded by definition, such as black nationalism. The impulse toward forming homogeneous groups of any kind feels politically retrograde to me and, even more, intellectually stultifying.

Of course, the only predictable thing about the landscapes of critical thought is how they changeconstantly and almost kaleidoscopically. With each new twist of the kaleidoscope, a particular theoretical orientation will reveal both useful new relevances and, unfortunately, often new ways of being beside the point. It is because of these frequent changes of gestalt that the ongoing outlines of a given person's theoretical work often become visible only in retrospect.

My interest in feminist theory began in 1970, as an undergraduate student in the very first Women's Studies course offered at Cornell University. Interestingly, this very challenging course was offered by the college of Home Economics, rather than Liberal Arts! At Yale University, where I did my doctoral work in the English department, there was no encouragement to pursue feminist work, to put it mildly. But in 1978, my first full-time teaching position plunged me and my new colleagues into an unusually turbulent and productive political situation. I went to teach at Hamilton College, a small, isolated, men's liberal-arts college that had just taken over a nearby all-female college. Thus, a very conservative male establishment was suddenly confronted with the entire range of gender issues that had been suppressed for the preceding century or more. All at once there were not only women students to be taught, but a critical mass of women faculty to be acculturated, and enormous changes to be made both in student life and in the college's curriculum. Furthermore, the male faculty and administrators had had no suspicion whatsoever that any of these adjustments would be necessary.

The result was that the small group of women faculty embarked together on an exhausting, but also immensely exhilarating, project of intensive education in feminist thought. We had to educate ourselves, our students, and our colleagues and institution, all at the same time. One factor that made things easier was that many of us had been hired on a long-term (4 years) but terminal basis — so there was nothing to deter us from taking professional risks in our adversarial relation to this college.

In the period around 1980 in the US, feminist theory was at a particularly exciting, almost reckless juncture. After a certain amount of additive scholarship in various disciplines, in which the writings or other achievements of a few women were simply added to the existing male canons, this was a time, instead, of very basic feminist challenges to the conceptual roots of the disciplines themselves. It was at this time that the claims of gender-free objectivity in the sciences, of phallic privilege in psychology, of the exclusive importance of statesmen and warriors in history, of purely stylistic value judgments in literature, were all subjected to feminist attack at a radical level. A few big concepts, such as "patriarchy," seemed to offer a lot of new critical leverage across disciplinary boundaries. As was the case with my colleagues at Hamilton College, the scholars pursuing this new knowledge were virtually all women, and our scholarship 
dealt almost exclusively with women's experience and women's oppression at the hands of men. In this heady context, I found myself developing the discussion of homosocial desire that underlies my 1985 book, Between Men.

The germ from which this work developed was a rather everyday psychological observation: I had noticed from personal experience and from my reading of British and American literature that whenever two men were in love with the same woman, the two men seemed to care much more about each other, as rivals, than they actually cared about the woman upon whom their desire was supposedly fixed. The more I thought about this observation in the context of emerging feminist theory, the more potentially significant it seemed — and the more disruptive, as well.

In the first place, it was disruptive to the implicit gender separatism that had been underlying most feminist theory to this point. Although it emerged from a context in which a group of women scholars were struggling to survive in a male-dominated academic situation, the book's paradigm of male homosocial desire suggested that in order to understand the fates of women, it was equally necessary to understand — not only the relations between men and women — but, in fact, the structuration of men's relationships with other men. In this respect, my work, along with other work such as Gayle Rubin's analysis of the "traffic in women" paradigm in anthropology and psychoanalysis, prefigured the largerscale transition in American scholarship from "women's studies" to "gender studies." Its implication was that gender needed to be studied as a complex representational system, a dynamic one with many levels of feedback and interaction, rather than just as the sum of its additive, apparently incompatible components (male and female).

"Male homosocial desire": the phrase in the subtitle of Between Men was intended to mark both discriminations and paradoxes. "Homosocial desire," to begin with, is a kind of oxymoron or contradiction in terms. "Homosocial" was at that time a word that had been occasionally used in history and the social sciences, where it described social bonds between persons of the same sex; it was a recently made-up word, obviously formed by analogy with "homosexual," and just as obviously meant to be distinguished from "homosexual." In fact, it was applied to such activities as "male bonding," which may, as it often is in American society, be characterized by intense homophobia, which is the fear and hatred of homosexuality. To draw the "homosocial" back into the orbit of "desire," of the potentially erotic, then, was to articulate a new hypothesis. I was suggesting the potential unbrokenness of a continuum between homosocial and homosexual - a continuum whose visibility, for men, in American society, is radically disrupted. "Male homosocial desire" was the name I gave to the entire continuum.

I chose the word "desire" rather than "love" to mark the erotic emphasis because, in literary critical and related discourse, "love" is more easily used to name a particular emotion, and "desire" to name a systemic structure; in this study, a series of arguments about the structural permutations of social impulses fuelled the critical dialectic. For the most part, I was using "desire" in a way analogous to the psychoanalytic use of "libido" — not for a particular affective state or emotion, but for the affective or social force, the glue, even when its manifestation is hostility or hatred or something less emotively charged, that shapes an important relationship. How far this force is properly sexual (what, historically, it means for something to 
be "sexual") was an active question.

My formulation was specific about male homosocial desire for a particular reason. It was one of the main projects of this study to explore the ways in which the shapes of sexuality, and even what counts as sexuality, both depend on and affect historical power relationships. A corollary is that in a society where men and women differ in their access to power, there will be important gender differences, as well, in the structure and constitution of sexuality.

For instance, the significant opposition between the "homosocial" and the "homosexual" seems to be much less thorough and dichotomous for women, at any rate in American society, than for men. At this particular historical moment, an intelligible continuum of aims, emotions, and valuations linked lesbianism with the other forms of women's attention to women: the bond of mother and daughter, for instance, the bond of sister and sister, women's friendship, "networking," and the active struggles of feminism. The continuum is crisscrossed with deep discontinuities — with much homophobia, with conflicts of race and class — but at the same time, for many women it seems a matter of simple common sense. However bitter the politics, however conflicted the feelings, it seems to make an obvious kind of sense to say that women in American society who love women, women who teach, study, nurture, suckle, write about, march for, vote for, give jobs to, or otherwise promote the interests of other women, are pursuing congruent and closely related activities. Thus the adjective "homosocial" as applied to women's bonds need not be pointedly dichotomized as against "homosexual"; it can intelligibly denominate the entire continuum.

The apparent simplicity — the unity of the continuum between "women loving women" and "women promoting the interests of women," extending over the erotic, social, familial, economic, and political realms, would not be so striking if it were not in strong contrast to the arrangement among males. When conservative male politicians get down to serious negotiations on "family values," they are men promoting men's interests. In fact, they embody Heidi Hartmann's definition of patriarchy: "relations between men, which have a material base, and which, though hierarchical, establish or create interdependence and solidarity among men that enable them to dominate women." Is their bond in any way congruent with the bond of a loving gay male couple? The conservative politicians would say no- disgustedly. Most gay couples would say no- disgustedly. But why not? Doesn't the continuum between "men-loving-men" and "men-promoting-the-interests-of-men" have the same intuitive force that it has for women?

Quite the contrary: much of the most useful 1970s' writing about patriarchal structures suggests that "compulsory heterosexuality" is built into male-dominated kinship systems, or that homophobia is a necessary consequence of such patriarchal institutions as heterosexual marriage. Clearly, however convenient it might be to group together all the bonds that link males to males, and by which males enhance the status of males — usefully symmetrical as it would be, that grouping meets with a prohibitive structural obstacle. From the vantage point of American society, at any rate, it has apparently been impossible to imagine a form of patriarchy that was not homophobic. Gayle Rubin writes, for instance, "The suppression of the homosexual component of human sexuality, and by corollary, the oppression of homosexuals, is ... a product of the same system whose rules and relations oppress women." 
The historical manifestations of this patriarchal oppression of homosexuals have been savage and nearly endless. Louis Crompton makes a detailed case for describing the history as genocidal. American society is brutally homophobic; and the homophobia directed against both males and females is not arbitrary or gratuitous, but tightly knit into the texture of family, gender, age, class, and race relations. US society, I argued in 1985, could not cease to be homophobic and have its economic and political structures remain unchanged.

Nevertheless, it wasn't clear that, because most patriarchies structurally include homophobia, therefore patriarchy structurally requires homophobia. In fact the example of the ancient Greeks demonstrates, I think, that while heterosexuality is necessary for the maintenance of any patriarchy, homophobia, against males at any rate, is not. In fact, for the Greeks, the continuum between "men loving men" and "men promoting the interests of men" appears to have been quite seamless.

It is clear, then, that there is an asymmetry in American society between, on the one hand, the relatively continuous relation of female homosocial and homosexual bonds, and, on the other hand, the radically discontinuous relation of male homosocial and homosexual bonds. A more recent example of that in the US is the way the Boy Scouts - the consummate male homosocial organization - have gone all the way to the Supreme Court to argue that it's essential to their mission to exclude gay male scouts and scoutmasters; while the Girl Scouts have never had a policy of excluding lesbians. But the example of the Greeks shows, in addition, that the structure of homosocial continuums is culturally contingent, not an innate feature of either "maleness" or "femaleness." Indeed, closely tied though it obviously is to questions of male vs. female power, the explanation would require a more exact mode of historical categorization than "patriarchy," as well, since patriarchal power structures (in Hartmann's sense) characterized both Athenian and American societies. In fact, Between Men was one of a group of theoretical projects in the 1980 's that very much put in question the usefulness of the overarching concept of patriarchy. Nevertheless, it was able to offer the following as an explicit axiom: that the historically differential shapes of male and female homosociality — such as they themselves may vary over time — will always be articulations and mechanisms of the enduring inequality of power between women and men.

Besides emerging from the scholarship on feminist theory, Between Men was also an attempt to think through the potential relations between feminism and the relatively new gay liberation movement. As a woman and a feminist writing (in part) about male homosexuality, I felt I needed to be especially explicit about the political groundings, assumptions, and ambitions of Between Men in that regard. My intention throughout was to conduct an anti-homophobic as well as feminist inquiry. However, most of the (little) published analysis up to that point of the relation between women and male homosexuality had been at a lower level of sophistication and care than either feminist or gay male analysis separately. In the absence of workable formulations about the male homosocial spectrum, this literature had, with only a few recent exceptions, subscribed to one of two, mutually exclusive, assumptions. The first assumption was that gay men and all women share a "natural," transhistorical alliance and an essential identity of interests — for example, in breaking down gender stereotypes. The second assumption, to the contrary, was that male homosexuality is an epitome, a personification, an effect, or perhaps a primary cause of woman-hating. 
I did not and do not believe either of these assumptions to be true. Especially because Between Men study discussed a continuum, a potential structural congruence, and a (shifting) relation of meaning between male homosexual relationships and the male patriarchal relations by which women are oppressed, it seemed very important to emphasize that I was not assuming or arguing either that patriarchal power is primarily or necessarily homosexual (as distinct from homosocial), or that male homosexual desire has a primary or necessary relationship to misogyny. Either of those arguments would be homophobic and, I believe, inaccurate. I was, however, arguing that homophobia directed by men against men is misogynistic, and perhaps transhistorically so. (By "misogynistic" I mean not only that it is oppressive of the so-called feminine in men, but that it is oppressive of women.) The greatest potential for misinterpretation lay in this part of the argument. Because "homosexuality" and "homophobia" are always historical constructions, because they are likely to concern themselves intensely with each other and to assume interlocking or mirroring shapes, because the theater of their struggle is likely to occur within individual minds or institutions as well as public, it is not always easy (sometimes barely possible) to distinguish them from each other. Thus, for instance, Freud's study of Dr. Schreber shows clearly that the repression of homosexual desire in a man who by any commonsense standard was heterosexual, occasioned paranoid psychosis; the psychoanalytic use that has been made of this perception, however, has been, not against homophobia and its crazy-making force, but against homosexuality itself — against homosexuals — on account of an association between "homosexuality" and mental illness. Similar confusions have marked discussions of the relation between "homosexuality" and fascism. As the historically constructed nature of "homosexuality" as an institution becomes more fully understood, it should become possible to understand these distinctions in a more exact and less prejudicious theoretical context.

Thus, I was arguing, profound and intuitable as the bonds between feminism and anti-homophobia often are in our society, the two forces are not the same. As the alliance between them is not automatic or transhistorical, it would be most fruitful if it were analytic and unpresuming. To shed light on the grounds, implications, and possibilities of that alliance was one of the main aims of Between Men.

The result of Between Men that made me happiest was that it did, indeed, seem to make available some terms in which male gay and antihomophobic activists could articulate their political identifications with feminist thought. These antiseparatist, nondualist formulations were among the theoretical advances that made possible the development of a strong, exciting, theoretically sophisticated gay and lesbian studies movement in universities around the United States.

The ambition of my next project, which culminated in the book Epistemology of the Closet, was to focus much more closely on the specific, systemic issues of knowledge and power surrounding male homo/heterosexual definition as it emerged in Western culture around the turn of the twentieth century. In this project I was building on my earlier antiseparatist argument. Just as it did not make sense to think of women and men as self-evidently distinct groups whose histories could be extricated from one another, similarly there is not an obvious, crisp, transhistorical boundary that separates homosexuals from heterosexuals. As a result, the history of homo/heterosexual definitions and prohibitions is an important 
element in any study of history or culture. In fact, one of the key questions raised by this work is how it has come about that THE meaning of "sexual orientation," at least in the west in the 20th century, has come to be: homosexual vs. heterosexual. Consider, after all, the many, very important dimensions, other than homo/hetero, along which sexuality varies from one person to another:

- For some people, the nimbus of "the sexual" seems scarcely to extend beyond the boundaries of discrete genital acts; to others, it enfolds them loosely or floats virtually free of them.

- Sexuality makes up a large share calf the self-perceived identity of some people, a small share of others'.

- Some people spend a lot of time thinking about sex, others little.

- Some people like to have a lot of sex, others little or none.

- Many people have their richest mental or emotional involvement with sexual acts that they don't do, or even don't WANT to do.

- For some people, it is important that sex be embedded in contexts that are full of meaning, narrative, and connectedness with other aspects of their life; for other people, it is important that they not be; there are others to whom it doesn't occur that they might be.

- For some people, the preference for a certain sexual object, act, role, zone, or scenario is so longstanding and durable that it can only be experienced as innate; for others, it appears to come late or to feel like a matter of choice or pure chance.

- For some people, the possibility of bad sex is unpleasant enough that their lives are strongly marked by its avoidance; for others, it isn't.

- For some people, sexuality provides a needed space of heightened discovery and cognitive excitement. For others, sexuality provides a needed space of routine, habituation, and cognitive relaxation.

- Some people like spontaneous sexual scenes, others like highly scripted ones, others like spontaneous-sounding ones that are nonetheless totally predictable.

- Some people's sexual orientation is intensely marked by autoerotic pleasures and histories sometimes more so than by any aspect of interpersonal object choice. For others the autoerotic possibility seems secondary or fragile, if it exists at all.

- Some people, homo-, hetero-, and bisexual, experience their sexuality as deeply embedded in a matrix of gender meanings and differentials. Others of each sexuality do not.

All of these dimensions of difference, and many others, were suppressed when "sexuality" became synonymous with "gender of object choice."

It was in the early 1990's, around the time that Epistemology of the Closet was published, that some elements of the gay and lesbian movement in the United States began to use the term "queer" in place of "gay" or "lesbian." I had not actually used the term queer in my book. But many of the nondualist theoretical tendencies of my work were very allied to those of the queer movement, so the book became closely identified with the emergence of queer theory.

In many ways, "queer" and "gay/lesbian" are overlapping terms; but some of their implications are very 
different. A lot of gay and lesbian politics, for example, accepts the concept of "sexual orientation" without questioning it in any way. Yet, exerting any pressure at all on "sexual orientation," you see that its elements are potentially quite heterogeneous. Its elements include:

- your biological (e.g. chromosomal) sex, male or female;

- your self-perceived gender assignment, male or female (which is supposed to be the same as your biological sex);

- the preponderance of your traits of personality and appearance, masculine or feminine (which is supposed to correspond to your sex and gender);

- the biological sex of your preferred partner;

- the gender assignment of your preferred partner (which is supposed to be the same as their biological sex);

- the masculinity or femininity of your preferred partner (which is supposed to be the opposite of your own);

- your self-perception as gay or straight (which is supposed to correspond to whether your preferred partner is your sex or the opposite);

- your preferred partner's self-perception as gay or straight (which is supposed to be the same as yours);

- your procreative choice (which is supposed to be yes if straight, no if gay);

- your preferred sexual act(s) (which are supposed to be insertive if you are male or masculine, receptive if you are female or feminine);

- your most eroticized sexual organs (which are supposed to correspond to the procreative capacities of your biological sex, and also to your insertive/receptive assignment);

- your sexual fantasies (which are supposed to be very similar to your sexual practice, but stronger in intensity);

- your main locus of emotional bonds (which is supposed to reside in your preferred sexual partner);

- your enjoyment of power in sexual relationships (which is supposed to be low if you are female or feminine, high if you are male or masculine);

- the people from whom you learn about your own gender and sex (who are supposed to correspond to yourself in all respects);

- your community of cultural and political identification (which is supposed to correspond to your own "identity");

and many, many more. While ordinary gay/lesbian politics take it for granted that these dimensions will all line up neatly with each other, forming a homogeneous and univocal whole.

And if not?

That's one of the things that "queer" can refer to: the open mesh of possibilities, gaps, overlaps, dissonances and resonances, lapses and excesses of meaning when the constituent elements of anyone's gender, or anyone's sexuality aren't made (or CAN'T BE made) to signify monolithically. The 
experimental linguistic, epistemological, representational, political adventures attaching to the very many of us who may at times be moved to describe ourselves as (among many other possibilities) pushy femmes, radical faeries, fantasists, fag hags or hag fags, drag queens or kings, clones, leather people, ladies in tuxedoes, feminist women or feminist men, masturbators, bulldykes, divas, opera queens, butch bottoms, storytellers, transsexuals, aunties, wannabes, lesbian-identified men or lesbians who sleep with men, or ... people able to relish, learn from, or identify with such folks.

Again, "queer" can mean something different: a lot of the way people use it is to denote, almost simply, same-sex sexuality, lesbian or gay, whether or not it is organized around multiple crossings of definitional lines. And given the historical and contemporary force of the prohibitions against every same-sex sexual expression, for anyone to disavow those meanings, or to displace them from the definitional center of the term, would be to evaporate any possibility of queerness itself.

At the same time, a lot of the most important recent work around "queer" expands the term along dimensions that cannot be reduced to gender and sexuality at all: the ways that race, ethnicity, postcolonial nationality criss-cross with these and other identity-constituting, identity-fracturing discourses, for example. Intellectuals and artists of many races whose sexual self-definition includes "queer" are using the leverage of this term to do a new kind of justice to the intersecting intricacies of language, skin color, migration, state, and culture. "Queer," to me, refers to a politics that values the ways in which meanings and institutions can be at loose ends with each other, crossing all kinds of boundaries rather than reinforcing them. What if the most productive junctures weren't the ones where everything means the same thing? Conventional gay/lesbian politics, for example, invests a great deal of energy in trying to create legal protections for the concept of "gay families," through such issues as gay marriage, artificial insemination, and gay adoption. But a queer analysis sees "the family" itself as an institution that is, at best, an unstable and probably unwholesome conjunction of the following, extremely varied functions:

a family name

- a sexual dyad

- a legal unit based on state-regulated marriage

- a circuit of blood relationships

- a system of companionship and support

- a building (the "home")

- a highly-charged boundary between "private" and "public"

- an economic unit of earning and taxation

- the prime site of economic consumption

- the prime site of cultural consumption

- a mechanism to produce, care for, and acculturate children

- a mechanism for accumulating material goods over several generations

a daily routine

- a unit in a community of worship 
a site of national formation

— and so forth. Looking at my own life, I see that — probably like most people — I have valued and pursued these various elements of family identity to quite different degrees (e.g. no use for reproduction, much need of companionship). But what's been consistent in this particular life, and in many queer lives, is an interest in not letting very many of these dimensions line up directly with each other at one time. I see it has been a dominant intuition for me that the most productive strategy (intellectually, emotionally) might be, whenever possible, to DIS-articulate them — from one another, to DIS-engage them - the bonds of blood, of law, of habitation, of privacy, of companionship and support - from the enforcement of their unanimity in the system called "family."

Looking at the current scene of sexuality politics in the United States, it appears that the insights of queer theory have become much less influential than they were in the 1990s, while the normalizing politics of the mainstream gay/lesbian movement have come to dominate the scene. The most visible political goals are demands to be allowed to conform: alongside the legitimization of same-sex marriage and families, they involve the inclusion of gay and lesbian people in the military, in the Boy Scouts, in electoral politics, and in mainstream religions.

It seems true to say that queer politics are both anti-separatist and anti-assimilationist: anti-separatist in the sense that we don't take it for granted that the world is neatly and naturally divided between homosexuals and heterosexuals, and anti-assimilationist in the sense that we are not eager to share in the privileges and presumptions of normality. Mainstream gay/lesbian politics, on the other hand, is paradoxically both separatist and assimilationist. It is separatist in its sense of identity, but at the same time all its goals involve the uncritical assimilation of gay people into the institutions of a very conservative culture.

It has become something of a truism, at the same time, that queer theory is mainly confined to academia, as a speculative, impractical, utopian way of thinking, while the non-theoretical mainstream movement is thought to represent the only way to get real things done in terms of actual politics. This may actually make some sense, but only if politics is defined exclusively in terms of elections and legislation, or in terms of institutional assimilation. Certainly, the conservative mainstream of the gay/lesbian movement is achieving some successes, and I do not want to diminish the importance of any success in an antihomophobic undertaking. Such successes are all too rare.

Yet, when the concept of "politics" in the United States gets narrowed down to electoral politics, there is also a huge price to pay. The most grievous price is that after two decades of activism, mainstream gay politics has now gone into complete denial about the AIDS crisis. Believe it or not, AIDS has disappeared as a public issue, and also as a gay issue, throughout the United States. Except for a few queer activists, the entire society seems to believe that AIDS is now being cured - which it is not - and that the number of people with AIDS has gone down — which it has not. Americans, including a great many gay men, are still dying of AIDS at obscenely young ages; but now they are doing it in the midst of an uncanny public silence. The media, both gay and straight, either ignore AIDS or treat it as something that now 
happens only in Africa, or to a worthless, nonwhite urban underclass of drug abusers. When there is discourse about AIDS in the American gay community, it involves heaping blame on any gay youth who are still getting infected with HIV.

It seems clear to me that the failure to remain engaged with AIDS issues is closely tied to the repudiation of queer thought by the conservative gay/lesbian movement in America. After all, it is only a queer analysis, not a strictly gay one, that can give us any help with this disease that respects no simple boundaries of identity. At this point in the American epidemic, the crucial issues go far beyond homophobia; they require an understanding of how homophobia and gay identities intersect historically with issues of race and poverty, with complex and phobic ideologies concerning drugs, with epidemiological models, with profound cultural meanings associated with sexuality, risk, and death, with the burgeoning prison system, with the global economics of medical development and marketing, and with the rapidly changing force fields of America's profit-driven medical delivery system.

The reason I choose to end with this particular emphasis today is, of course, the relatively new and already gravely frightening stage of the AIDS epidemic as it now begins to impinge visibly on many Asian countries. It seems so urgent at this moment to make available any conceptual tools that can help make sense of this disease and the social/psychological matrices in which it is embedded. The continuing worldwide epidemic also, of course, mercilessly exposes every weakness in the limited and US-centered theories that we Americans can bring to bear on it. My deepest wish is that Japanese and other Asian thinkers will be able to generate fuller and more efficacious wisdom that they will be willing to share with those of us in the west. 